\title{
NOTES
}

\section{"I KNEW REUBEN FARWELL AS A FIRST-CLASS SOLDIER": AN UNPUBLISHED WHITMAN LETTER}

While researching a presentation for The Historical Society of Washington, D.C., on Walt Whitman's hospital service, I came across a previously unpublished letter from Whitman in the pension file of Whitman's soldier-friend and Civil War veteran Reuben Farwell (see back cover). ${ }^{1}$ Written at the request of Reuben's widow Ann, the 1884 letter is addressed to the Commissioner of Pensions in support of Mrs. Farwell's application for survivor benefits. The letter is written entirely in Whitman's hand, on both sides of a single sheet of unlined white paper, 8 by $10^{1 / 2}$ inches, folded vertically in thirds, and horizontally in half. On one side, in the middle fold, the letter is addressed:

To the

Commissioner of Pensions Washington DC

On the opposite side, is written:

\author{
328 Mickle street \\ Camden New Jersey \\ October 51884
}

I knew Reuben Farwell as a first-class soldier (it was in 1863 or '64) of a Michigan Regiment-he was in Ward A, Armory Square Hospital, Dr Bliss Superintendent-I was with him off \& on for some months \& remember the case perfectly well. He had a very bad foot wound, \& I should judge it something that would deteriorate his health \& more or less incapacitate him through life afterward - till his death- $\&$ even tend toward that event-which as I understand occurred about a year ago.

I strongly recommend the granting a pension to his widow Ann E. Farwell.

\section{Very respectfully \\ Walt Whitman}

Armed with Whitman's testimony and other supporting documentation, Mrs. Farwell was awarded a government pension for herself and her daughter Nettie. ${ }^{2}$

Saluted in Whitman's Memoranda During the War as a "typical soldier," Reuben Farwell served with the 1st Michigan Cavalry. A farmer in Plymouth, Michigan, before the war, ${ }^{4}$ Farwell enlisted as a private on August 16, 1861, at the age of twenty-two. ${ }^{5}$ His military papers described him as 5 foot 5 inches tall, with a light complexion offset by black eyes and brown hair. This "typical soldier" of the American Civil War participated in many memorable battles, including Second Bull Run (August 30, 1862), Gettysburg (July 3, 1863), 
and U. S. Grant's Forty Days Campaign (Spring 1864). While serving with the Michigan Brigade under General George Armstrong Custer at Brandy Station, Virginia, on October 11, 1863, Farwell received a shell wound in his left foot. It landed him in Armory Square Hospital, where Farwell met Walt Whitman. ${ }^{6}$

Reuben Farwell was one of the scores of soldiers whose recuperation was fostered by the "ordinary cheer and magnetism" of Whitman's personality, dispensed as a form of medicine by that unique hospital visitor $(M D W, 18)$. Indeed, the poet's claim in "The Wound-Dresser," that "Many a soldier's kiss dwells on these bearded lips," was literally true in the case of Farwell. Years after his release from the military hospital, Reuben longingly remembered Whitman's bedside visits: "Walt my dear old Friend = how I would lik [sic] to grasp your hand and give you a kiss as I did in the days of yore, what a satisfaction it would be to me."

The hospital in which Farwell was a patient received high marks from Whitman. "The Wards are very comfortable, with new floors and plaster walls, and models of neatness. I am not sure but this is a model hospital, after all, in important respects" $(M D W, 38)$. Armory Square's location on the Mall at 7th Street, S.W. (the current site of the Smithsonian's Air and Space Museum), provided ready access for the wounded arriving from the Potomac River wharves situated a few blocks south. Dr. David Willard Bliss, the hospital's surgeonin-charge, was lauded by Whitman as "one of the best surgeons in the army" $(M D W, 50)$. Like Farwell, Bliss had been a Michigan Volunteer who served originally with that state's $3 \mathrm{~d}$ Infantry, and later as a surgeon in the U.S. Volunteers. $^{8}$

Farwell was released from Armory Square hospital on April 18, 1864. He served the remaining four months of his tour and was mustered out of the $1 \mathrm{st}$ Michigan Cavalry on August 22.

As his military career had been "typical" of a generation of American young men, so Farwell's post-War life followed a familiar path. Returning home to farm, Farwell soon married, and raised a daughter. ${ }^{9}$ Like that of so many War veterans, his life was marked by ill health. Farwell's wife recalled that, "Reuben ... served three years in the Civil War came home almost a cripple never able to work I took care of him. We got along as best we could." ${ }^{10}$ Sinking spells, bouts of chronic diarrhea, and a debilitating stroke eventually forced Farwell to lease out his 35-acre Nankin, Michigan, farm to tenants and rely on a veteran's disability pension.

As with many of the soldier patients he befriended, Whitman corresponded intermittently with Farwell. A spate of letters between them in 1864 was followed by a ten-year silence. Whitman's preparation in 1875 of his Memoranda During the War apparently caused him to seek out several soldier friends, including Farwell. ${ }^{11}$ A February 5th postcard from Whitman elicited an immediate response from Farwell on the 11th: "But you have not forgoten your littel Michigan friend yet-Well i have not forgotten my Hospital Friend yet and I hope that I never will" (Shively, 141). Whitman returned this heartfelt sympathy: "O how I should like to see you, every day, dear Mitch-my own dear boy and comrade of the war-the hospital-I have to sit here alone much of the time, and think of those old times" (Corr., 2:328). 
Reuben Farwell died on May 19, 1883. Whitman was able to provide one last service to his "little Mitch," as the poet called Reuben $(M D W, 59)$, by helping Farwell's widow and daughter obtain a pension. Ann Farwell survived her husband by 49 years, and never re-married. She joined Reuben in death on December 29, 1932, on the couple's 68th wedding anniversary.

\section{The Washington Friends of Walt Whitman MARTIN G. MURRAY}

\section{NOTES}

1 See "Pension Record for Reuben Farwell, Company H, 1st Michigan Cavalry, 18611864," Record Group Number 15, Records of the Veterans Administration, National Archives, Washington, D.C. (hereafter referred to as Farwell's Pension Record). The letter does not appear in Edwin Haviland Miller, ed., Walt Whitman: The Correspondence (New York: New York University Press, 1961, 1964, 1969, 1977).

2 Although there is no extant letter from Mrs. Farwell to Whitman requesting his help, the fact that Whitman in September 1884 wrote down her address in his notebook indicates that she had written to him around that time (Walt Whitman, Daybooks and Notebooks, ed. William White [New York: New York University Press, 1978], 2:341).

3 Walt Whitman, Memoranda During the War (Camden: 1875-1876), 59.

4 Farwell was born in Lyons, Wayne County, New York, one of seven children (all boys) born to Leroy and Olive Farwell. Some time before 1860, the family moved to Plymouth, Michigan. (Data based on Census Records, National Archives, Record Group 29.)

5 See "Compiled Military Service Record of Reuben Farwell, Company H, 1st Michigan Cavalry, 1861-1864," Record Group Number 94, Records of the Adjutant General's Office, National Archives (hereafter referred to as Farwell's Military Service Record).

6 Farwell was admitted to Armory Square Hospital in Washington, D.C., on October 12,1863 , and given Bed Number 33, in Ward A. He remained in the hospital until January 28, 1864, when he was furloughed home for a month, returning again on February 27. (See Farwell's Military Service Record.)

7 Charley Shively, Drum Beats (San Francisco: Gay Sunshine Press, 1989), 141. All of the extant letters from Farwell to Whitman are included in Shively's collection.

8 Bliss was thirty-five when he enlisted in the 3rd Michigan Infantry on June 10, 1861. For Bliss's military career, see "Compiled Military Service Record of D. W. Bliss, Companies F and S, 3rd Michigan Infantry, 1861," and also "Personal Papers of Medical Officers and Physicians, Medical Officers Files, for D. W. Bliss, Surgeon, U.S. Volunteers, 1861-1865," Record Group Number 94, Records of the Adjutant General's Office, National Archives.

9 Farwell married Ann Knickerbocker, a 22-year-old woman from Livonia, Michigan, on December 29, 1864. Ann Farwell gave birth to the couple's first and only child, a daughter they named Nettie, on March 28, 1870. (See Farwell's Pension Record.)

10 See September 18, 1916, letter in Farwell's Pension Record.

11 In 1874 and 1875, Whitman corresponded with Benton Wilson, William Stansberry, Manvill Winterstein, and Bethuel Smith. With Farwell, they were included in Whitman's list of typical soldiers in $M D W, 59$. 